\title{
AEROSOL PARTICLE FORMATION IN THE LITHUANIAN HEMI-BOREAL FOREST
}

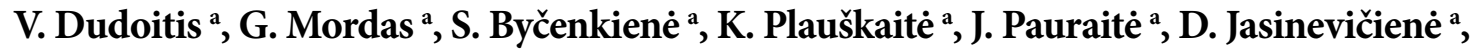 \\ V. Marozas ${ }^{\mathrm{b}}$, G. Pivoras ${ }^{\mathrm{b}}$, G. Mozgeris ${ }^{\mathrm{b}}$, A. Augustaitis ${ }^{\mathrm{b}}$, and V. Ulevičius ${ }^{\text {a }}$ \\ ${ }^{a}$ SRI Center for Physical Sciences and Technology, Sauletekio 3, 10257 Vilnius, Lithuania \\ ${ }^{\mathrm{b}}$ Aleksandras Stulginskis University, Studentu 13, 53362 Akademija, Lithuania \\ Email: vadimas.dudoitis@ftmc.lt
}

Received 24 April 2018; revised 13 August 2018; accepted 15 October 2018

\begin{abstract}
Aerosol particle observations are needed to determine the conditions of particle formation and growth in different environments. This research focuses on new particle formation (NPF) events in the hemi-boreal forest environment at the Aukštaitija Integrated Monitoring Station (IMS) $\left(55^{\circ} 26^{\prime} \mathrm{N}\right.$ and $26^{\circ} 04^{\prime} \mathrm{E}, 170 \mathrm{~m}$ above the sea level). The parameterisation of aerosol particle Nucleation I (3-10 nm), Nucleation II (10-20 nm) and Aitken (20-100 nm) modes was performed, their inputs to the total particle number concentration (PNC) and distribution were assessed. It has been estimated that around $40 \%$ of days in spring and $22 \%$ in summer were NPF event days. The highest contribution of Nucleation mode I aerosol particles was observed in June, reaching up to $38 \%$ of the total PNC values. The mean growth rate $(G R)$ and condensation sink $(C S)$ values at the Aukštaitija IMS in April and May were $2.9 \mathrm{~nm} \cdot \mathrm{h}^{-1}, 1.30 \cdot 10^{-3} \mathrm{~s}^{-1}$ and $5.3 \mathrm{~nm} \cdot \mathrm{h}^{-1}, 1.35 \cdot 10^{-3} \mathrm{~s}^{-1}$, respectively. The $G R$ and $C S$ values were well in agreement with the results obtained from other hemi-boreal forest sites in the Baltic Sea region.
\end{abstract}

Keywords: new particle formation, nucleation, SMPS, hemi-boreal forest

PACS: 92.60.Mt

\section{Introduction}

As our planet year after year is experiencing a record breaking temperature anomaly (see https:// berkeleyearth.org/global-temperatures-2017/, aerosol studies from various locations are important to understand how fast the environment is changing and how the nature adapts to the climate change. One of the natural processes of aerosol particle number concentration (PNC) increase in the atmosphere is through the nucleation. It can be observed in different environments: on coastlines [1, 2], in forested areas [3-5] and in other vegetation habitats [6, 那. Terrestrial vegetation significantly contributes to new particle formation (NPF) by releasing into the atmosphere a vast array of precursors, which start the initial process of nucleation: biogenic volatile organic compounds (VOCs), es- pecially monoterpene emission by trees [ 8 , 9], iodine (I) and dimethyl sulphide $\left(\left(\mathrm{CH}_{3}\right)_{2} \mathrm{~S}\right)$ sources from algae activity in the marine and Arctic environments [10, 11]. This process involves the subnanometre cluster formation from a condensable vapour, the growth of homogenous clusters to the sizes detectable by aerosol measurement techniques [12, 13]. It is well established that sulphuric acid $\left(\mathrm{H}_{2} \mathrm{SO}_{4}\right)$ is one of the main chemical compounds in the atmosphere participating in the NPF process [14]. The process of $\mathrm{SO}_{4}{ }^{2-}$ ions involvement in the NPF events is fairly well explained in the case of urban environments, where emission sources of $\mathrm{SO}_{2}$ gases and other atmospheric pollutants are abundant 15 17]. A different situation arises in clean environments, such as hemi-boreal forest, where $\mathrm{H}_{2} \mathrm{SO}_{4}$ contribution to NPF and growth is diminished due to the presence of VOCs [9, 18, 19]. 
Therefore, additional observations are needed to determine the mechanisms by which particles nucleate and grow in different environments.

The aim of this study was NPF observation in the Lithuanian hemi-boreal forest environment, and estimation of the nucleation events during the warm season and the nucleation process characterisation by the aerosol particle formation rate $(F R)$, growth rate $(G R)$ and condensation sink (CS). In addition, the variation in the input of each mode on the total PNC has been estimated. In this study, aerosol particles were subgrouped into Nucleation mode I and Nucleation mode II, in size ranges of 3-10 $\mathrm{nm}$ and $10-20 \mathrm{~nm}$, respectively, and Aitken mode $(20-100 \mathrm{~nm})$ [20]. It is known that the peak of aerosol particle mode, produced during the nucleation events, resides in the size range below $10 \mathrm{~nm}$ [1]. Nucleation mode I mainly represents freshly formed aerosol particles from primary sources, where particle growth is driven through the condensational growth [21]. In the case of Nucleation mode II, the aerosol particle formation can be attributed either to natural or to anthropogenic emission sources [22-25].

\section{Methodology}

\subsection{Measurement site description}

The measurement campaign was performed at the Aukštaitija integrated monitoring station (IMS) $\left(55^{\circ} 27^{\prime} \mathrm{N}\right.$ and $26^{\circ} 04^{\prime} \mathrm{E} ; 170 \mathrm{~m}$ above the sea level), located in Aukštaitija National Park, in the NorthEastern part of Lithuania (Fig. 1). The nearest resi- dential areas are Tauragnai and Utena (total population of 32000 ) in the west and Ignalina (population of 6000 ) in the southeast. The measurement site was located in the hemi-boreal forest, bordering Utenas Lake in the southwest and Rūgšteliškis Village in the southeast. This hemi-boreal forest is mainly dominated by Scots pines, the rest of the area is filled with Norway spruces and birch trees [26, 27].

\subsection{Measurement technique}

The aerosol particle number size distribution was measured in a size range of 3-110 nm, using a scanning mobility particle sizer (SMPS). It was composed of two units: a condensation particle counter (CPC, TSI model 3776) and a differential mobility analyzer (DMA, TSI model 3085). The SMPS working parameters were the following: aerosol flow $1.5 \pm 0.1 \mathrm{~L} \cdot \mathrm{min}^{-1}$, sheath flow $6.0 \pm 0.1 \mathrm{~L} \cdot \mathrm{min}^{-1}$, and positive high voltage varied from $10^{1}$ to $\sim 10^{4} \mathrm{~V}$. The duration of the up-scan was $4 \mathrm{~min}$ and the whole cycle was repeated every $5 \mathrm{~min}$. A custom impactor $(0.071 \mathrm{~cm}, T S I)$ placed in front of the SMPS ensured that large particles did not distort the calculations, as an effective cut size diameter $\left(D_{50 \%}\right)$ of $560 \mathrm{~nm}$ was well above the measurement size range. Aerosol particles were neutralised by passing through a radioactive ${ }^{85} \mathrm{Kr}$ neutraliser (TSI model 3077A). The particle diffusion losses were evaluated using the Gormley-Kennedy equation for a cylinder [28]. The multiple charge correction was applied using the AIM software provided by TSI.

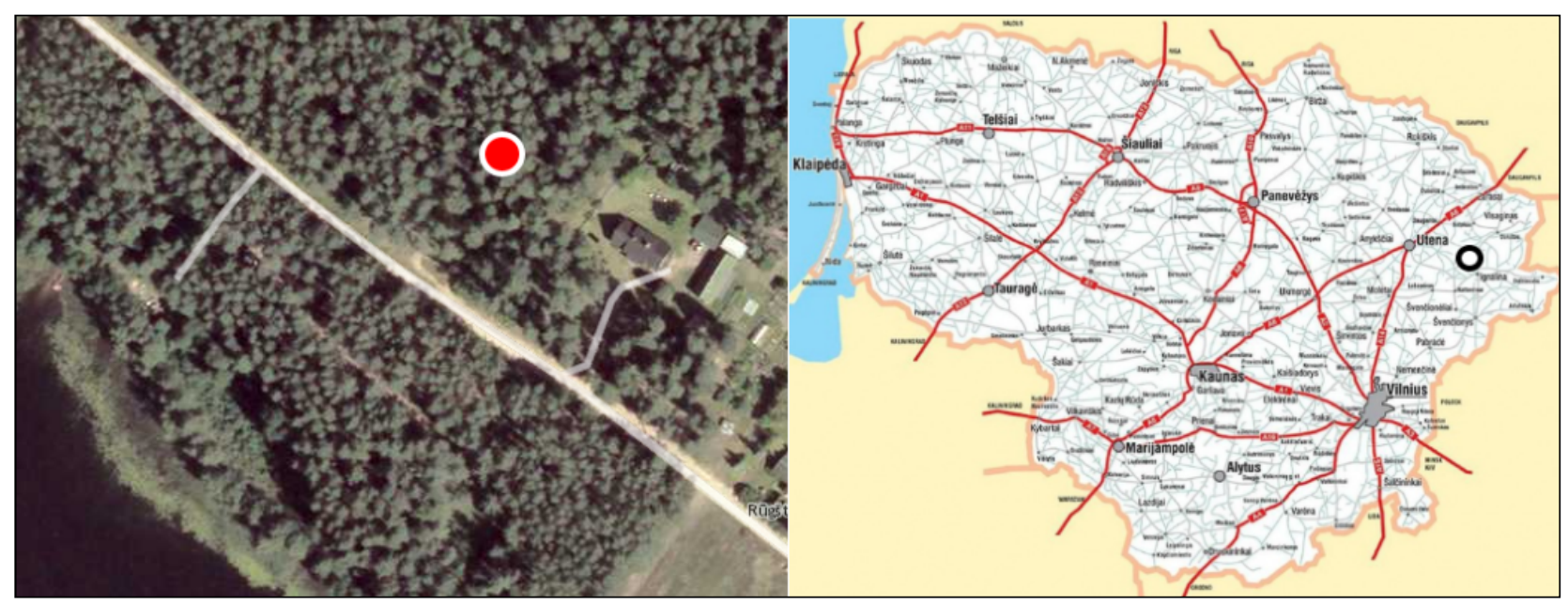

Fig. 1. The forest measurement site at the Aukštaitija Integrated Monitoring Station. 
$\mathrm{A} \mathrm{PM}_{10}$ inlet was installed $4 \mathrm{~m}$ above the ground, attached to a stainless steel tube of $16 \mathrm{~mm}$ inner diameter. The total sampled aerosol flow was $5.5 \pm 0.1 \mathrm{~L} \cdot \mathrm{min}^{-1}$. Inside the building this aerosol flow was split into two separate lines. A stainless steel tube of $3 \mathrm{~mm}$ inner diameter and a flow rate of $1.5 \pm 0.1 \mathrm{~L} \cdot \mathrm{min}^{-1}$ was used by SMPS. However, before the sampled aerosol flow reached SMPS, the aerosol humidity was reduced by using a nafion dryer (Perma Pure LLC, model MD-110-72S-4). The measured data quality control was performed periodically during the measurement campaign. It consisted of aerosol and sheath flow rates verification and CPC zero checking. The DMA maintenance was done once per year using 70 and $150 \mathrm{~nm}$ polystyrene particles. An automatic weather monitoring station(DL2e, Delta-T Device Co.) was assembled in the sampling area to measure meteorological parameters locally, such as air temperature and relative humidity ( $T$ and $R H$; RHT2nl-02 sensor, Delta-T Device Co.). The data were logged at 1 -h intervals.

\subsection{NPF event classification}

The classification of the NPF was based on the principles described in Refs. [29, 30]:

Type I: The growth of newly formed particles is clearly distinguishable in the particle number size distribution plots. The main physical parameters - growth rate $(G R)$ and formation rate $(F R)$ - characterising the event can be determined without doubt.

Type II: The cluster of new particles is present, however, the shape of the growing particle mode is unclear, and thus the retrieving physical parameters (GR and $F R$ ) are possible only for some of these events.

Non-event: The days when no new particles in the Nucleation particle mode were formed.

Undefined: It is unclear whether the new particle formation occurred, the event did not fulfil the requirements of the criteria mentioned above.

\subsection{Physical parameterisation of new particle growth and formation}

For each nucleation event, the $G R$ was calculated graphically from the contour plots. The GR can be expressed as in Ref. [31]:

$$
\frac{\mathrm{d} r}{\mathrm{~d} t}=\frac{m_{v} \beta_{\mathrm{m}} D C}{r \rho} .
$$

Here $r$ is the particle radius, $m_{v}$ is the molecular mass of condensable vapour, $\beta_{\mathrm{m}}$ is the transitional correction factor for mass flux, $D$ is the diffusion coefficient, $C$ is the concentration of the condensable vapour, and $\rho$ is the particle density. Eq. (1) can be integrated from $r_{0}$ to $r$ to obtain the condensable vapour concentration:

$$
\begin{aligned}
& C=\rho\left\{\frac{r^{2}-r_{0}^{2}}{2}+[4 /(3 \alpha)-0.623] \lambda\left(r-r_{0}\right)+\right. \\
& \left.+0.623 \lambda^{2} \ln \frac{\lambda+r}{\lambda+r_{0}}\right\} .
\end{aligned}
$$

$\alpha$ is the mass accommodation coefficient (i.e. sticking probability) and $\lambda$ is the mean free path. The parameters $\mathrm{d} r / \mathrm{d} t$ and $\mathrm{d} N_{3 \mathrm{~nm}} / \mathrm{d} t$ can be obtained directly from the measurements. The condensation sink (CS) is $4 \pi \cdot D \cdot C S^{\prime}$, and $C S^{\prime}$ is integrated over the aerosol size distribution:

$$
C S^{\prime}=\int r \beta_{\mathrm{m}}(r) n(r) \mathrm{d} r=\sum_{i} \beta_{\mathrm{m}} r_{i} N_{i} .
$$

The $\beta_{\mathrm{m}}$ is expressed by terms of the Knudsen number $(K n)$ and the sticking coefficient $(\alpha)$ as follows:

$$
\beta_{\mathrm{m}}=\frac{K n+1}{0.377 \cdot K n+1+4 / 3 \cdot \alpha^{-1} \cdot K n^{2}+4 / 3 \cdot \alpha^{-1} \cdot K n} .
$$

The $K n$ and $\alpha$ are typically assumed to be unity. In the molecular regime where $K n \gg 1$, we have $C S \propto r^{2}$. On the other hand, in the continuum regime where $K n \ll 1$, we get $\beta_{\mathrm{m}}=1$ and $C S \propto r$. However, typically tropospheric aerosol also includes the transitional regime and CS $\propto a$, where $1<a<2$. It was equal to 1 for this case.

\section{Results and discussion}

\subsection{Occurrence of new particle formation events at the Aukštaitija IMS}

The measurements of the particle number size distribution in a range of 3-100 $\mathrm{nm}$ were performed at the Aukštaitija IMS hemi-boreal forest from 8 April to 7 October 2016. Three distinct particle modes were classified as Nucleation mode I (3-10 nm), 
Nucleation mode II (10-20 nm) and Aitken mode (20-100 nm). By applying the NPF classification scheme, the days were grouped into event and nonevent days (Table 1). The total number of analysed days was 158 . Herewith, in total $36 \mathrm{NPF}$ event days were observed and classified into Type I (12 events) and Type II ( 24 events). There were 25 non-event and 97 undefined days. The NPF events mostly occurred during the period of April-June 2016. It was estimated that $40 \%$ of events occurred during the spring, $22 \%$ during the summer and no events were depicted in the autumn due to scarce measurement data. The contribution of each aerosol particle mode to the total PNC was determined (Fig. 2).

Table 1. The classification of NPF event days at the Aukštaitija IMS.

\begin{tabular}{|c|c|c|c|c|c|}
\hline \multirow[t]{2}{*}{ Month } & \multicolumn{5}{|c|}{ Days } \\
\hline & ڤ્ટ & $\underset{ٍ}{\beth}$ & 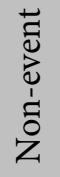 & 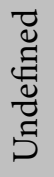 & $\begin{array}{l}\text { तే } \\
\text { 음 }\end{array}$ \\
\hline APR & 7 & 2 & 7 & 7 & 23 \\
\hline MAY & 3 & 7 & 7 & 7 & 24 \\
\hline JUN & 2 & 9 & 1 & 16 & 28 \\
\hline JUL & 0 & 2 & 3 & 20 & 25 \\
\hline AUG & 0 & 4 & 4 & 16 & 24 \\
\hline $\mathrm{OCT}^{*}$ & 0 & 0 & 3 & 4 & 7 \\
\hline Whole season & 12 & 24 & 25 & 97 & 158 \\
\hline
\end{tabular}

* In October 7 days out of the whole month were covered.

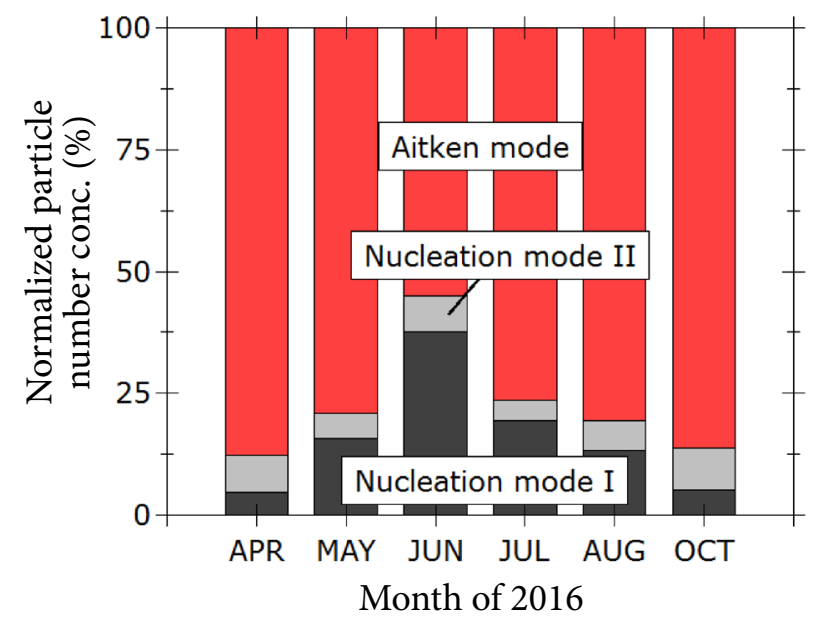

Fig. 2. Aerosol particle mode contribution to the total PNC.
The highest contribution to the total PNC was attributed to the aerosol particles of Aitken mode. It contributed from $55 \%$ in June to $88 \%$ in April. The contribution of Nucleation mode I varied from $5 \%$ in October to $38 \%$ in June of the total PNC. Nucleation mode II had no meaningful contribution during the whole measurement campaign. Its contribution varied from 4 to $9 \%$ and did not have any clear trend.

\subsection{Particle number concentration analysis}

The total PNC ranged from $150 \mathrm{~cm}^{-3}$ (5th percentile) to $14960 \mathrm{~cm}^{-3}$ (95th percentile) during the whole measurement period (Fig. 3(a)). The monthly averages of total PNC were lowest $\left(235 \mathrm{~cm}^{-3}\right)$ in October and highest $\left(3970 \mathrm{~cm}^{-3}\right)$ in August. It should be noted that the fluctuations in the total PNC were also highest during the summer months and lowest in the autumn. The monthly median values were lower than the averages of total PNC in all cases, except for October, thus suggesting that the aerosol particle size distribution is positively skewed. The Nucleation mode I data revealed that the highest variability in particle concentration was observed during the spring season (Fig. 3(b)). During this period most NPF events, classified as Type I (Table 1), had occurred.

One of the highest monthly PNC values in Nucleation mode I were measured in the period from May to July. During that period the 95th percentile lowered from 3620 to $2160 \mathrm{~cm}^{-3}$ and the highest monthly average $\left(1150 \mathrm{~cm}^{-3}\right)$ was observed in June. Although the mean and median values of Nucleation mode I were higher in the summer than in the spring, the number of NPF events was smaller in comparison to the spring, 40 and $22 \%$, respectively (Table 1 ). In clean environment the high mean PNC in Nucleation mode I is likely to indicate the presence of a new particle emission source located in the surrounding area. In general, the GR for aerosol particles of sub-10 nm size in the atmosphere is in a range from 1 to $20 \mathrm{~nm} \cdot \mathrm{h}^{-1}$ [31], in this work it was estimated to be $\sim 5 \mathrm{~nm} \cdot \mathrm{h}^{-1}$. The transition of aerosol particles from Nucleation mode I to mode II occured in a 1-2-h period. During the warm period, the air masses are usually transported at speeds from 20 to $60 \mathrm{~km} \cdot \mathrm{h}^{-1}$ in this geographic region [32]. During the transport of air masses from the nearest urban areas, such as Utena and Ignalina, aerosol 

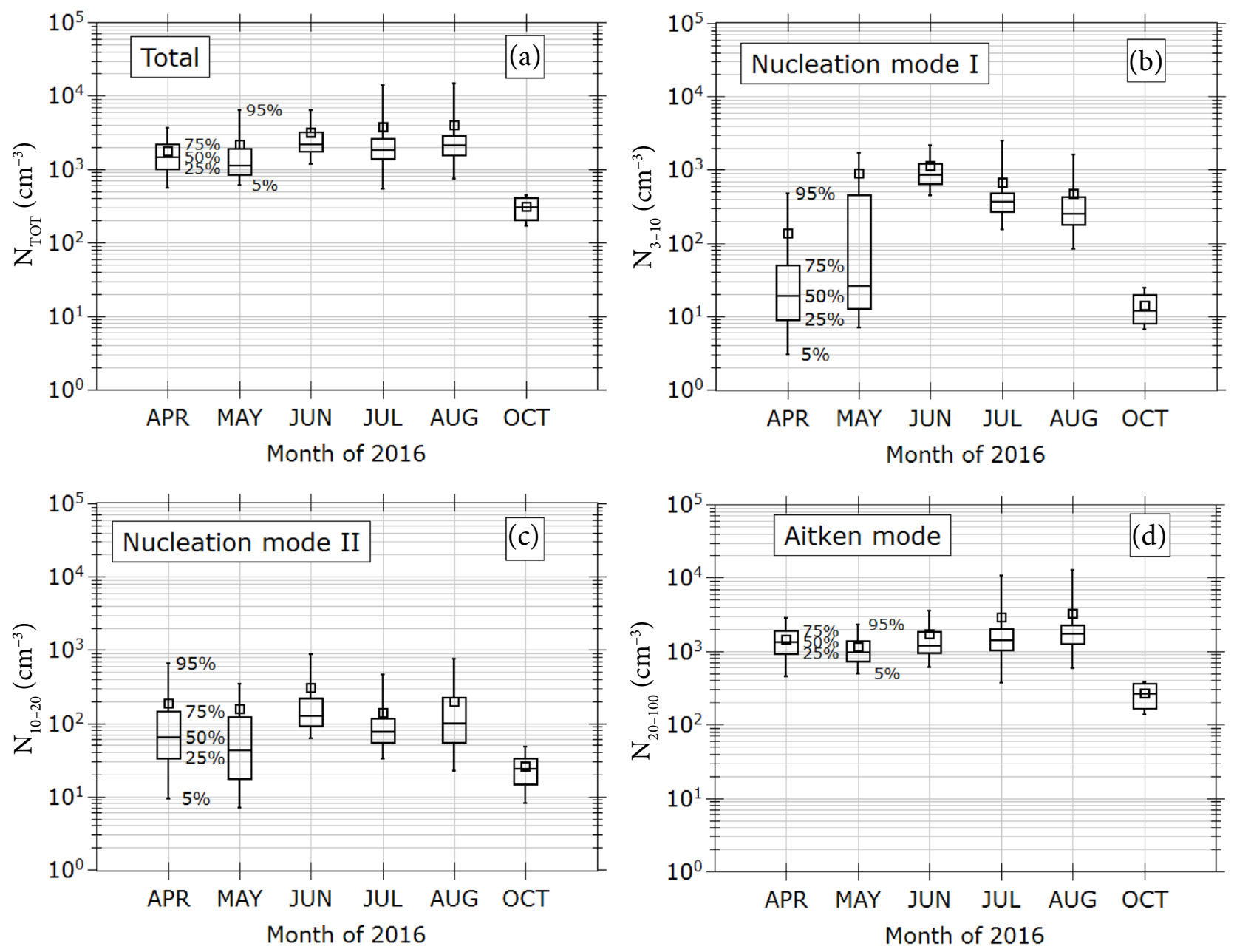

Fig. 3. Box plots of the monthly average PNC of total (a), Nucleation mode I (b), Nucleation mode II (c) and Aitken mode (d). The 5th and the 95th percentiles (whiskers), quartile $\mathrm{Q}_{1}$ and $\mathrm{Q}_{3}$ (box), median (horizontal line) and mean (square).

particles would grow substantially to be detected in Nucleation mode II or Aitken mode. Thus, the probable source for increased monthly PNC values in Nucleation mode I during the summer was biogenic activity in the forested area around the Aukštaitija IMS. However, sporadic contamination from local biomass burning sources could not be avoided during the measurement period.

The contribution of Nucleation mode II in the hemi-boreal forest environment was low - the 95 th percentile was well below $900 \mathrm{~cm}^{-3}$ during the whole measurement campaign (Fig. 3(c)). The Aitken mode PNC had the highest value of $3300 \mathrm{~cm}^{-3}$ in August (Fig. 3(d)). The Aitken mode data from the Aukštaitija IMS were compared to the aerosol PNC in a size range of 30$100 \mathrm{~nm}$ from the stations located in the Northern and Central Europe (Table 2). The stations were selected according to their type, which is similar to the Aukštaitija IMS designation [33]. The Aitken mode mean PNC (1 $\left.800 \mathrm{~cm}^{-3}\right)$ during the whole period was one of the highest (except for Preila) in the Northern Europe. For comparison in Central Europe the highest $\mathrm{PNC}$ values in this size range were measured at the K-Puszta and Kosetice stations, 2700 and $2420 \mathrm{~cm}^{-3}$, respectively. It should be considered that in clean environments the PNC concentrations usually decrease during the autumn [29, 34], and in the Aukštaitija IMS dataset the autumn data was underrepresented. Collecting more data from the SMPS measurement in autumn would have decreased PNC values for the whole campaign, in general. There was a tendency of PNC increase in the Aitken mode during the summer, the same tendency was observed at the forest stations, SMEAR II and Pallas, both 
Table 2. Data obtained from Ref. [32], representing the mean values of aerosol PNC in a size range of 30$100 \mathrm{~nm}$ for the period of 2008-2009 from the stations located in Northern and Central Europe. The stations are classified by their type and region, the mean, median, 5th and 95th percentiles of 2008-2009 dataset are presented.

\begin{tabular}{c|c|c|c|c|c|c|c}
\hline Station & $\begin{array}{c}\text { Station } \\
\text { code }\end{array}$ & Station type & Region & $\begin{array}{c}5 \text { th } \\
\text { percentile }\end{array}$ & Mean & Median & $\begin{array}{c}95 \text { th } \\
\text { percentile }\end{array}$ \\
\hline Aspvreten & ASP & regional background/forest & $\begin{array}{c}\text { Northern } \\
\text { Europe }\end{array}$ & 220 & 1090 & 940 & 2490 \\
\hline Birkenes & BIR & rural/forest & $\begin{array}{c}\text { Northern } \\
\text { Europe }\end{array}$ & 60 & 620 & 450 & 1650 \\
\hline Pallas & PAL & remote/above tree line & $\begin{array}{c}\text { Northern } \\
\text { Europe }\end{array}$ & 30 & 370 & 180 & 1310 \\
\hline Preila & PLA & regional background/marine & $\begin{array}{c}\text { Northern } \\
\text { Europe }\end{array}$ & 350 & 2590 & 1830 & 4930 \\
\hline $\begin{array}{c}\text { Aukštaitija } \\
\text { IMS }\end{array}$ & - & regional background/forest & $\begin{array}{c}\text { Northern } \\
\text { Europe }\end{array}$ & 440 & 1800 & 1150 & 5470 \\
\hline SMEAR II & SMR & regional background/forest & $\begin{array}{c}\text { Northern } \\
\text { Europe }\end{array}$ & 150 & 950 & 760 & 2390 \\
\hline Vavihill & VHL & regional background/marine & $\begin{array}{c}\text { Northern } \\
\text { Europe }\end{array}$ & 320 & 1460 & 1280 & 3240 \\
\hline K-Puszta & KPO & regional background/rural & $\begin{array}{c}\text { Central } \\
\text { Europe }\end{array}$ & 800 & 2700 & 2160 & 6390 \\
\hline Kosetice & OBK & regional background/rural & $\begin{array}{c}\text { Central } \\
\text { Europe }\end{array}$ & 750 & 2420 & 2030 & 5400 \\
\hline $\begin{array}{c}\text { Hohenpeis- } \\
\text { senberg }\end{array}$ & HBH & alpine/rural & $\begin{array}{c}\text { Central } \\
\text { Europe }\end{array}$ & 340 & 1130 & 990 & 2400 \\
\hline
\end{tabular}

* In the case of Aukštaitija IMS, the data from the Aitken mode $(20-100 \mathrm{~nm})$ during the measurement campaign were compared.

located in Finland [33]. Oppositely, on the Baltic sea coastal environments, the variation in the monthly average PNC of Aitken mode had a general tendency towards increasing in the spring at Preila (Lithuania) [2], Aspvreten and Vavihill (Sweden) [33].

\subsection{Diurnal patterns of nucleation events}

The classical NPF event of Type I was observed on 12 April 2016 (Fig. 4(a)). Fresh particles started to form at 10:30 (GMT+2), followed by a significant growth up to $40 \mathrm{~nm}$ in size at 18:00 (GMT+2). Such intense type of particle growth is referred as 'banana shaped' particle number size distribution [30]. In April particle burst in the $\mathrm{Nu}$ cleation modes (Fig. 5( $(\mathrm{a}, \mathrm{b})$ ) usually started at 11:00 (GMT+2) and lasted till the evening, with the peak concentration values reached at 14:0015:00 (GMT+2). Usually, Type I events start to form around the noon, when the solar radiation is most intense. Therefore, we refer to these events as midday. Due to the condensation growth and coagulation of newly nucleated particles, the PNC of Nucleation mode II started to increase with 1-h delay, at 12:00 (GMT+2), and reached its highest value at 15:00 (GMT+2). In April the air temperature had the classical trend with reaching the minimum $+2.5^{\circ} \mathrm{C}$ at sunrise and the maximum $+11^{\circ} \mathrm{C}$ at noon. In May the evening bursts of newly nucleated particles were common (Fig. 5(c, d)). Though the initial start of NPF events was still present during the noon, the PNC values in the evening were dominant. In this case PNCs of both $\mathrm{Nu}^{-}$ cleation modes reached maximum values at 18:00 $(\mathrm{GMT}+2)$ without a delay. In May the most common events were classified as Type II and due to the time of their occurrence we refer to them as the evening events (Fig. 4(b)). The PNC of Aitken mode was stable and did not vary during the day both in April and in May (Fig. 5( $(a, c))$. In addition, 'break type' events, classified as Type II, were 

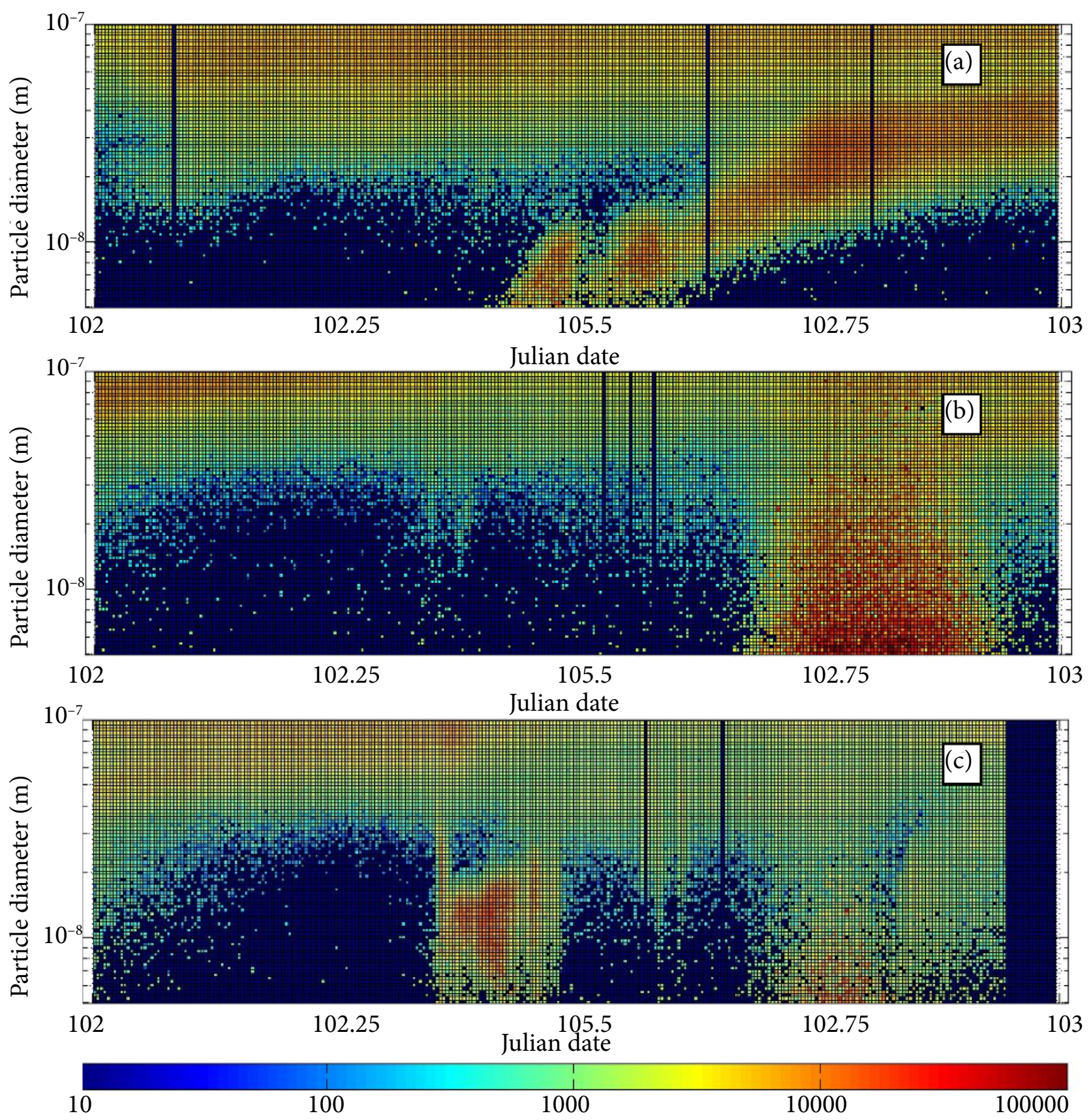

Fig. 4. Examples of NPF events. The midday event, classified as Type I, occurring on 12 April 2016 (a), the evening event, classified as Type II, occurring on 23 May 2016 (b) and the 'breaking type' event, classified as Type II, occurring on 7 May 2016 (c).

observed in May as well (Fig. 4(c)). The 'break type' event was similar to the midday one, however the growth of Nucleation mode particles was not observed in this case. This was due to the fact that the initial NPF event had started not at the measurement site. Newly nucleated particles travelled from the surrounding locations in the vicinity. After the change of the air mass direction, the observation of the nucleation process was terminated.

\subsection{Parameterisation of aerosol particles}

The estimated average growth rate and CS values (Eqs. 1, 3) at the Aukštaitija IMS in April and May were $2.9 \mathrm{~nm} \cdot \mathrm{h}^{-1}, 1.30 \cdot 10^{-3} \mathrm{~s}^{-1}$ and $5.3 \mathrm{~nm} \cdot \mathrm{h}^{-1}$, $1.35 \cdot 10^{-3} \mathrm{~s}^{-1}$, respectively. The GR and $C S$ were compared with the results from other measurement sites, located in the hemi-boreal forests of the Baltic Sea region. The average GR and $C S$ values were $3.9 \mathrm{~nm} \cdot \mathrm{h}^{-1}, 4.8 \cdot 10^{-3} \mathrm{~s}^{-1}$ in the Aspvreten (Sweden), 


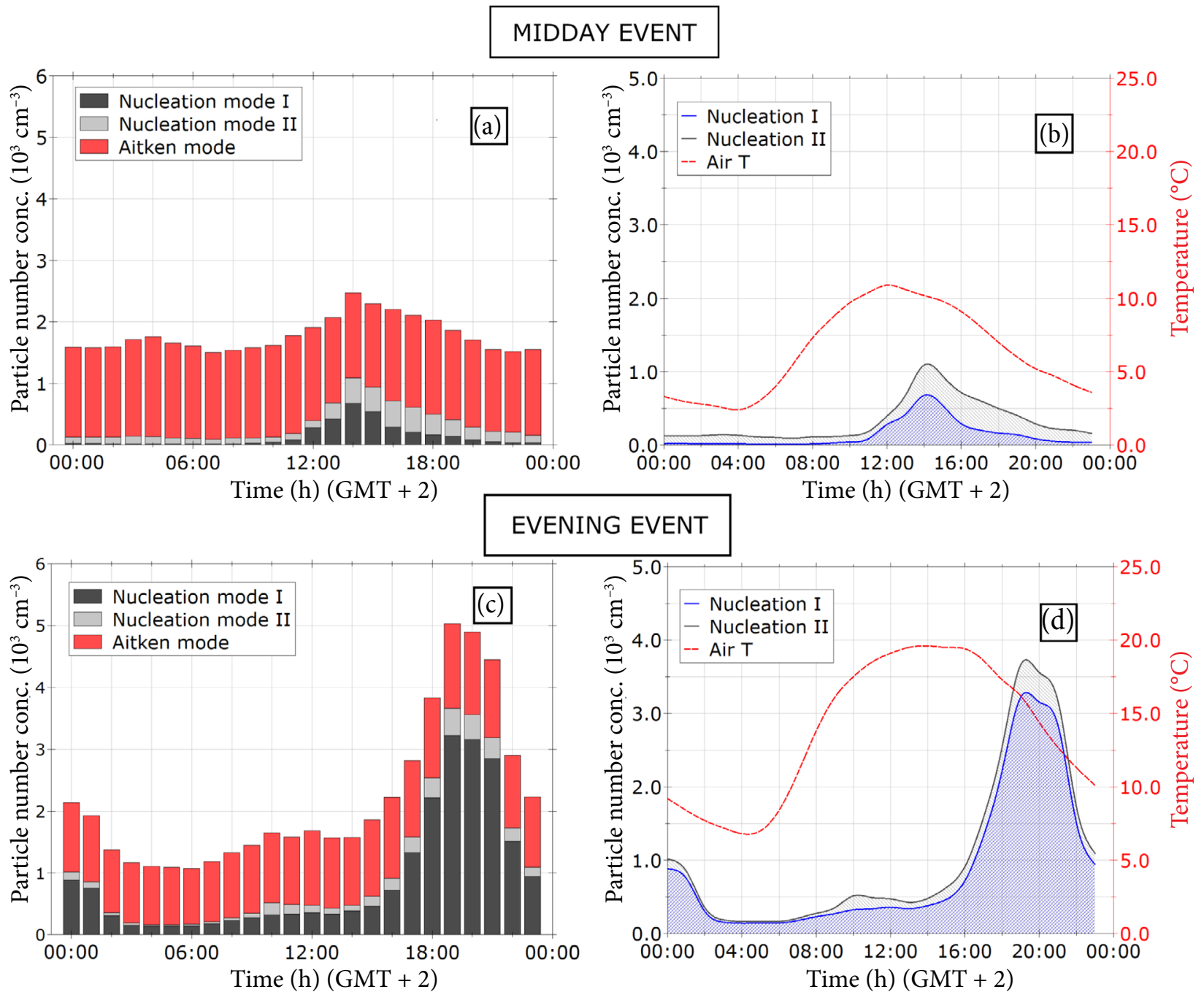

Fig. 5. The diurnal variation of PNC monthly values in Nucleation and Aitken modes during April $(a, b)$ and May 2016 (c, d), the monthly average of air temperature diurnal variation (b, d).

$3.0 \mathrm{~nm} \cdot \mathrm{h}^{-1}, 3.2 \cdot 10^{-3} \mathrm{~s}^{-1}$ in Hyytiälä (Finland) and $2.5 \mathrm{~nm} \cdot \mathrm{h}^{-1}, 1.2 \cdot 10^{-3} \mathrm{~s}^{-1}$ in Pallas (Finland) stations [4, 30]. In comparison, the $G R$ values for the stations situated in the south of the Baltic Sea were higher than the ones from the north. The CS mean values from the Aukštaitija IMS were similar to Pallas' ones. This suggests that biogenic VOCs were some of the main factors, influencing the aerosol formation process in this area.

\section{Conclusions}

During the warm season (April-October 2016), the measurements of aerosol particle number size distribution were performed at the Aukštaitija IMS. The monthly variations in the $\mathrm{PNC}$ of $\mathrm{Nu}-$ cleation mode I, Nucleation mode II and Aitken mode have been studied. The increase of particle number concentration (PNC) values in $\mathrm{Nu}$ cleation mode I during the summer was caused mainly by biogenic activity in the forested area surrounding the Aukštaitija IMS.

During the investigation period, 36 days (23\%) were identified as NPF events: 12 days of Type I and 24 days of Type II. Most of the NPF events occurred in the spring ( $40 \%$ of all days), while in the summer $22 \%$ of all days were NPF events.

The contribution of Nucleation mode I (3$10 \mathrm{~nm}$ ) was always dominating over Nucleation mode II (10-20 nm) during the NPF events. The highest contribution of Nucleation mode I was $38 \%$ of the total PNC and was observed in June. Aerosol particles in Aitken mode contributed to the total PNC from $55 \%$ in June to $88 \%$ 
in April. No diurnal pattern for the Aitken mode particles was observed during the investigation period.

The mean aerosol particle growth rate $\left(4.1 \mathrm{~nm} \cdot \mathrm{h}^{-1}\right)$ and condensation sink $\left(1.32 \cdot 10^{-3} \cdot \mathrm{s}^{-1}\right)$ were well in agreement with the values observed from other forested areas in the Baltic Sea region.

\section{Acknowledgements}

The research leading to these results was funded by the National Research Programme 'Sustainability of Agro-, Forest and Water Ecosystems', Project FOREstRESS (No. SIT-3/2015).

\section{References}

[1] C.D. O'Dowd and T. Hoffmann, Coastal new particle formation: a review of the current state-ofthe-art, Environ. Chem. 2(4), 245 (2005), https:// doi.org/10.1071/EN05077

[2] G. Mordas, K. Plauškaite, N. Prokopčiuk, V. Dudoitis, C. Bozzetti, and V. Ulevičius, Observation of new particle formation on Curonian Spit located between continental Europe and Scandinavia, J. Aerosol Sci. 97, 38-55 (2016), https://doi. org/10.1016/j.jaerosci.2016.03.002

[3] T.M. Ruuskanen, M. Kaasik, P.P. Aalto, U. Horrak, M. Vana, M. Martensson, Y.J. Yoon, P. Keronen, G. Mordas, D. Ceburnis, et al., Concentrations and fluxes of aerosol particles during the LAPBIAT measurement campaign at Varrio field station, Atmos. Chem. Phys. 7(14), 3683-3700 (2007), https://doi.org/10.5194/acp-7-3683-2007

[4] M.D. Maso, A. Hyvarinen, M. Komppula, P. Tunved, V.-M. Kerminen, H. Lihavainen, Y. Oviisanen, H.-C. Hansson, and M. Kulmala, Annual and interannual variation in boreal forest aerosol particle number and volume concentration and their connection to particle formation, Tellus B 60(4), 495-508 (2008), https://doi. org/10.1111/j.1600-0889.2008.00366.x

[5] T. Suni, M. Kulmala, A. Hirsikko, T. Bergman, L. Laakso, P.P. Aalto, R. Leuning, H. Cleugh, S. Zegelin, D. Hughes, et al., Formation and characteristics of ions and charged aerosol particles in a native Australian Eucalypt forest, Atmos.
Chem. Phys. 8(1), 129-139 (2008), https://doi. org/10.5194/acp-8-129-2008

[6] V. Vakkari, H. Laakso, M. Kulmala, A. Laaksonen, D. Mabaso, M. Molefe, N. Kgabi, and L. Laakso, New particle formation events in semi-clean South African savannah, Atmos. Chem. Phys. 11(7), 3333-3346 (2011), https://doi.org/10.5194/ acp-11-3333-2011

[7] M. Kanakidou, J.H.Seinfeld, S.N. Pandis, I. Barnes, F.J. Dentener, M.C. Facchini, R. Van Dingenen, B. Ervens, A. Nenes, C.J. Nielsen, et al., Organic aerosol and global climate modelling: a review, Atmos. Chem. Phys. 5(4), 1053-1123 (2005), https://doi.org/10.5194/acp-5-1053-2005

[8] J. Kesselmeier, U. Kuhn, A. Wolf, M. Andreae, P. Ciccioli, E. Brancaleoni, M. Frattoni, A. Guenther, J. Greenberg, P. De Castro Vasconcellos, T. De Oliva, T. Tavares, and P. Artaxo, Atmospheric volatile organic compounds (VOC) at a remote tropical forest site in central Amazonia, Atmos. Environ. 34(24), 4063-4072 (2000), https://doi. org/10.1016/S1352-2310(00)00186-2

[9] A. Kiendler-Scharr, J. Wildt, M.D. Maso, T. Hohaus, E. Kleist, T.F. Mentel, R. Tillmann, R. Uerlings, U. Schurr, and A. Wahner, New particle formation in forests inhibited by isoprene emissions, Nature 461(7262), 381-384 (2009), https://doi. org/10.1038/nature08292

[10]J.D. Allan, P.I. Williams, J. Najera, J.D. Whitehead, M.J. Flynn, J.W. Taylor, D. Liu, E. Darbyshire, L.J. Carpenter, R. Chance, S.J. Andrews, S.C. Hackenberg, and G. McFiggans, Iodine observed in new particle formation events in the Arctic atmosphere during ACCACIA, Atmos. Chem. Phys. 15(10), 5599-5609 (2015), https://doi.org/10.5194/ acp-15-5599-2015

[11]J.D. Cline and T.S. Bates, Dimethyl sulfide in the Equatorial Pacific Ocean: A natural source of sulfur to the atmosphere, Geophys. Res. Lett. 10(10), 949-952 (1983), https://doi.org/10.1029/ GL010i010p00949

[12] A.J. Pettibone, Toward a Better Understanding of New Particle Formation, $\mathrm{PhD}$ thesis (University of Iowa, 2009), https://ir.uiowa.edu/etd/420

[13]M. Kulmala, Atmospheric science: How particles nucleate and grow, Science 302 (5647), 
1000-1001 (2003), https://doi.org/10.1126/science.1090848

[14]M. Sipilä, T. Berndt, T. Petäjä, D. Brus, J. Vanhanen, F. Stratmann, J. Patokoski, R.L. Mauldin, A.-P. Hyvärinen, H. Lihavainen, and M. Kulmala, The role of sulfuric acid in atmospheric Nucleation, Science 327(5970), 1243-1246 (2010), https://doi.org/10.1126/science.1180315

[15]J. Gao, T. Wang, X. Zhou, W. Wu, and W. Wang, Measurement of aerosol number size distributions in the Yangtze River delta in China: Formation and growth of particles under polluted conditions, Atmos. Environ. 43(4), 829-836 (2009), https://doi.org/10.1016/j.atmosenv.2008.10.046

[16]Z.J. Wu, L. Poulain, W. Birmili, J. Grob, N. Niedermeier, Z.B. Wang, H. Herrmann, and A. Wiedensohler, Some insights into the condensing vapors driving new particle growth to CCN sizes on the basis of hygroscopicity measurements, Atmos. Chem. Phys. 15(22), 1307113083 (2015), https://doi.org/10.5194/acp-1513071-2015

[17]A. Hamed, W. Birmili, J. Joutsensaari, S. Mikkonen, A. Asmi, B. Wehner, G. Spindler, A. Jaatinen, A. Wiedensohler, H. Korhonen, K.E.J. Lehtinen, and A. Laaksonen, Changes in the production rate of secondary aerosol particles in Central Europe in view of decreasing $\mathrm{SO}_{2}$ emissions between 1996 and 2006, Atmos. Chem. Phys. 10(3), 1071-1091 (2010), https:// doi.org/10.5194/acp-10-1071-2010

[18]B. Bonn and G.K. Moorgat, New particle formation during a- and b-pinene oxidation by $\mathrm{O}_{3}, \mathrm{OH}$ and $\mathrm{NO}_{3}$, and the influence of water vapour: particle size distribution studies, Atmos. Chem. Phys. 2(3), 183-196 (2002), https://doi.org/10.5194 acp-2-183-2002

[19] A. Metzger, B. Verheggen, J. Dommen, J. Duplissy, A.S.H. Prevot, E. Weingartner, I. Riipinen, M. Kulmala, D.V. Spracklen, K.S. Carslaw, and U. Baltensperger, Evidence for the role of organics in aerosol particle formation under atmospheric conditions, Proc. Natl. Acad. Sci. 107(15), 6646-6651 (2010), https://doi.org/10.1073 pnas.0911330107
[20]A. Wiedensohler, D.S. Covert, E. Swietlicki, P. Aalto, J. Heintzenberg, and C. Leck, Occurrence of an ultrafine particle mode less than $20 \mathrm{~nm}$ in diameter in the marine boundary layer during Arctic summer and autumn, Tellus B 48(2), 213-222 (1996), https://doi.org/10.3402/tellusb. v48i2.15887

[21]T. Nieminen, K.E.J. Lehtinen, and M. Kulmala, Sub-10 $\mathrm{nm}$ particle growth by vapor condensation - effects of vapor molecule size and particle thermal speed, Atmos. Chem. Phys. 10(20), 9773-9779 (2010), https://doi.org/10.5194/acp10-9773-2010

[22]T. Hussein, A. Puustinen, P.P. Aalto, J.M. Makela, K. Hameri, and M. Kulmala, Urban aerosol number size distributions, Atmos. Chem. Phys. 4(2), 391-411 (2004), https://doi.org/10.5194/acp-4391-2004

[23] V. Ulevičius, S. Byčenkienè, C. Bozzetti, A. Vlachou, K. Plauškaite, G. Mordas, V. Dudoitis, G. Abbaszade, V. Remeikis, A. Garbaras, et al., Fossil and non-fossil source contributions to atmospheric carbonaceous aerosols during extreme spring grassland fires in Eastern Europe, Atmos. Chem. Phys. 16(9), 5513-5529 (2016), https://doi.org/10.5194/acp-16-5513-2016

[24]R. Zhang, A. Khalizov, L. Wang, M. Hu, and $\mathrm{W}$. Xu, Nucleation and growth of nanoparticles in the atmosphere, Chem. Rev. 112(3), 1957-2011 (2012), https://doi.org/10.1021/cr2001756

[25]I. Riipinen, T. Yli-Juuti, J.R. Pierce, T. Petaja, D.R. Worsnop, M. Kulmala, and N.M. Donahue, The contribution of organics to atmospheric nanoparticle growth, Nat. Geosci. 5(7), 453-458 (2012), https://doi.org/10.1038/ngeo1499

[26]A. Augustaitis, I. Augustaitienè, M. Baugarten, S. Bičenkienè, R. Girgždienè, G. Kulbokas, E. Linkevičius, V. Marozas, M. Mikalajūnas, G. Mordas, et al., Tree-ring formation as an indicator of forest capacity to adapt to the main threats of environmental changes in Lithuania, Sci. Total Environ. 615, 1247-1261 (2018), https://doi.org/10.1016/j.scitotenv.2017.09.169

[27]A. Augustaitis, D. Šopauskienè, and I. Baužiené, Direct and indirect effects of regional air pollution on tree crown defoliation, Balt. For. 16(1), 
23-34 (2010), https://www.balticforestry.mi.lt/bf/ index.php?option=com_content\&view $=$ article\& catid=12\&id=41

[28]P.G. Gormley and M. Kennedy, Diffusion from a stream flowing through a cylindrical tube, Proc. R. Ir. Acad. A 52, 163-169 (1948-1950), https:// www.jstor.org/stable/20488498

[29] M. Dal Maso, M. Kulmala, I. Riipinen, R. Wagner, T. Hussein, P.P. Aalto, and K.E.J. Lehtinen, Formation and growth of fresh atmospheric aerosols: eight years of aerosol size distribution data from SMEAR II, Boreal Env. Res. 10(October), 323-336 (2005), http://citeseerx.ist.psu.edu/viewdoc/dow nload?doi=10.1.1.562.3319\&rep=rep1\&type $=\mathrm{pdf}$

[30]H.E. Manninen, T. Nieminen, E. Asmi, S. Gagne, S. Häkkinen, K. Lehtipalo, P. Aalto, M. Vana, A. Mirme, S. Mirme, et al., EUCAARI ion spectrometer measurements at 12 European sites - analysis of new particle formation events, Atmos. Chem. Phys. 10(16), 7907-7927 (2010), https://doi.org/10.5194/acp-10-7907-2010

[31] M. Kulmala, H. Vehkamäki, T. Petäjä, M. Dal Maso, A. Lauri, V.-M. Kerminen, W. Birmili, and P.H. McMurry, Formation and growth rates of ultrafine atmospheric particles: a review of observations, J. Aerosol Sci. 35(2), 143-176 (2004), https://doi.org/10.1016/j.jaerosci.2003.10.003

[32]J. Pauraitè, G. Mordas, S. Byčenkiené, and V. Ulevičius, Spatial and temporal analysis of organic and black carbon mass concentrations in Lithuania, Atmosphere 6(8), 1229-1242 (2015), https://doi.org/10.3390/atmos6081229

[33]A. Asmi, A. Wiedensohler, P. Laj, A.-M. Fjaeraa, K. Sellegri, W. Birmili, E. Weingartner, U. Baltensperger, V. Zdimal, N. Zikova, et al., Number size distributions and seasonality of submicron particles in Europe 2008-2009, Atmos. Chem. Phys. 11(11), 5505-5538 (2011), https:// doi.org/10.5194/acp-11-5505-2011

[34]K. Plauškaitė, N. Špirkauskaitè, S. Byčenkienė, S. Kecorius, D. Jasinevičienè, T. Petelski, T. Zielinski, J. Andriejauskienè, R. Barisevičiūtè, A. Garbaras, P. Makuch, V. Dudoitis, and V. Ulevičius, Characterization of aerosol particles over the southern and South-Eastern Baltic Sea, Mar. Chem. 190, 13-27 (2017), https://doi. org/10.1016/j.marchem.2017.01.003

\title{
AEROZOLIO DALELIỤ SUSIDARYMAS LIETUVOS PUSIAU BOREALINIUOSE MIŠKUOSE
}

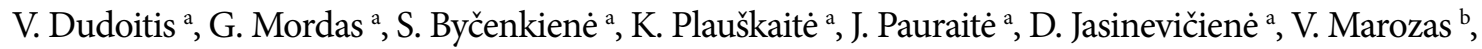 \\ G. Pivoras ${ }^{\text {b }}$, G. Mozgeris ${ }^{b}$, A. Augustaitis ${ }^{\text {b }}$, V. Ulevičius ${ }^{\text {a }}$ \\ ${ }^{a}$ VMTI Fiziniu ir technologijos mokslu centras, Vilnius, Lietuva \\ ${ }^{\mathrm{b}}$ Aleksandro Stulginskio universitetas, Kauno r., Lietuva
}

\begin{abstract}
Santrauka
Aerozolio dalelių susidarymo ir augimo procesų ivvairiose aplinkose stebèjimai yra būtini siekiant ištirti sąlygas, prie kurių šie reiškiniai vyksta. Darbe nagrinèjamas naujų aerozolio dalelių susidarymas Aukštaitijos kompleksinio monitoringo stoties (IMS) miškuose. Ivertinti pagrindiniai fizikiniai aerozolio dalelių 1-osios nukleacinès (3-10 nm), 2-osios nukleacinès (10-20 nm) ir Aitkeno modų (20-100 nm) parametrai, nustatytas šių modų bendras indèlis ị skaitinị aerozolio dalelių dydžių pasiskirstymą ir koncentraciją. Pavasarị buvo nustatyti
\end{abstract}

$40 \%$ nauju daleliu susidarymo atvejai, vasara - $22 \%$. Didžiausias 1-osios nukleacinès modos indèlis ị skaitinę daleliu koncentraciją siekè iki 38 \% nuo bendros koncentracijos, jis buvo stebimas $2016 \mathrm{~m}$. birželio ménesį. Vidutinès aerozolio dalelių augimo greičio $(G R)$ ir kondensacinio nuotèkio $(C S)$ vertès $2016 \mathrm{~m}$. balandžio-gegužès mèn. sudarè atitinkamai $2,9 \mathrm{~nm} \cdot \mathrm{h}^{-1}, 1,30 \cdot 10^{-3} \mathrm{~s}^{-1}$ ir $5,3 \mathrm{~nm} \cdot \mathrm{h}^{-1}, 1,35 \cdot 10^{-3} \mathrm{~s}^{-1}$. Šio tyrimo metu nustatytos $G R$ ir $C S$ vertès yra artimos vertèms, gautoms iš kitų Baltijos jūros regiono miškingų vietovių. 